\title{
Fog-Signals in Fleets
}

\section{Commander H. W. Brent K.N.}

To cite this article: Commander H. W. Brent K.N. (1871) Fog-Signals in Fleets, Royal United Services Institution. Journal, 15:63, 136-156, DOI: $10.1080 / 03071847109417040$

To link to this article: http://dx.doi.org/10.1080/03071847109417040

\section{册 Published online: 11 Sep 2009.}

Submit your article to this journal

Џll Article views: 2

Q View related articles $₫$ 


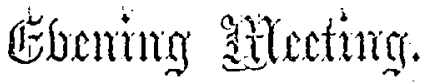

Nonday, February 6th, 1Sז1.

Peltr-Aduinat $\Lambda$. P. RYDLR, in the Chair:

NAMES of MSEJIEER who joincd the Institution between the 31st Januny and the Gth February.

ANNUAL.

Cocluanc, II. S., R. T., Mrajor, th Fis.

Maniell, I.S. S., Lt.-Col. 102nd Regt.

Tiutley, J. Leris, Capt. 2d Midx. Art. Yoluntecrs.

FOG-SIGNALS IN I'LEETS.

By. Commander Il. WT. Brexr, R.N.

Suddex changes of temperatue, or rather the fact of the existence in one district of a high temperature, while close by, the weather is cold, is the cause of fog, which, occurring at sea, and enveloping a ship, reduces that ship to the state of a man, walking in the noonday along the liigh road, suddenly struck blind, leaving the other senses in full force, and it may be quickened by the calamity. $A$ deuse fog at sea is not an alarming thing, but shutting out all that can be seen, you so suddenly become dependent on different means of finding your way, that it naturally causes anxiety to those in charge of ships. and every means that can bo found, should be made use of to lighten that anxiety. At sea in $n$ fog, being primarily dependent on the sense of hearing, noise of some sort to attract attention naturally takes the most prominent place to assist a ship in her morements: a blind man fecls his Tay literaliy as he goes along, bit a ship camnot actually do that, although in sea phrase the term "groping her way" is applied to a ship in a fog; this is figuratively doing the same as the blind man on shore, and consists in listening attentively, going slowly while uncertain, souidiug often when near the land, and noticing also most attentively. the speed and the time occupied in going certain nnmbers of miles.

I purpose this evening to spenk on "log-signalling" as regards Her Majesty's Navy only, more especially that part of it which relates to a fleet; for a fog cnveloping a flcet that has a certain object in viow, is of more conseguence than to a single ship. Thie Orders in Council for prercnting "collisions at sea" lay" down what a single ship is to do to warn others of her approach, and how she may tell generally what is approaching. $\Delta$ fleet has not only these Orders, but that part of the. 
night signal-book which refers to fogs for guidanco; these fog-signals cone therefore within the scope of this paper.

Although everyone who has been at sea, has been frequently in a fog; jet they do not occur sufficieutly often for Officers and men to be familiar enough with fog-signals; a flect itself may also be so seldom in a fog that the fog-signals are but little studied; the day, and now night, signalling requiring so much attention, for-signals are left until they are wanted, when it is expected that everything will be found cicar and simple, and that the most ordinary individual will have not the slightest difficulty in either making or understanding the siguals, or following the instructions laid down.

log-signalling 'should of all others be most distinct, regular, and simple, depending as it must entirely on sound; it should not be too quick, nor too slow, but made in a uniform stendy way, always at the same rate, and in the same style; its instructions should be clear and distinct; the most simple means of communication that can be found should be used, at the same time taking care that the best instruments are supplied for making the signals, that even the ignorant may find the rork so ready to their hands, and so easy of understanding, that the most stupid of them camnot fail to know, not only how to make the signals, but also understand the signals made in return.

In the fog-signals as at present laid down, signals by guns only, are in use, but since the introduction of the flashing night-signals. by Gaptain Colomb, the same principle, with long and short sonnds on the steam-whistle and fog-horn, has been much used. The loudest and most distinct noise being wanted, the firing of guns at regular and good intervals is of course the best method, as a gun, if the charge is sufficiently heary, can be heard farther than any other noise at present made afloat, but there being a limit to guu signals, the flashing-signals by the steam-whistle, fog-horn, or bugle are a necessary, and I think $a$ sufficient adjunct. I beliere the present fog-signals, with the assistance of the flashing-signals, both somewhat altered, to be quite sulticient for all the wants of our leets, my reason for saying so is from the experiments I hare made, and the information I havo received, both of which I intend to lay before you this evening.

Gun-fog-signals coming first, and knowiug there were some difficulties connected with the present system, through the intervals at which the guns were fired, namely the preparative guns at intervals of $\mathbf{5}$ seconds, and the signal guns at intervals of 30 seconds, when at Portland, in June, 1869, by permission of Sir Thomas Symonds, then in command of the Channel Fleet, I sent two boom-boats Iashed together, ench carrying a 12-pounder Armstrong gun, outside the Breakwater, and went with a party of sigualmen to the opposite side of the hill, to listen to the guns; the signalmen of the "Minotaun". on board their own ship, by order of Captain Goodezough, also listening and taking notes.

The experiments were to try the best interrals for distinguishing. casily the guns fired, whether the present system of 5 seconds was not too quick and the 30 seconds too loug; if so, what intermediate time would be better. Twenty-fire series were tried, and both partios agreed in opiwion regarding the intervals. The scries were as follows:I. 2 

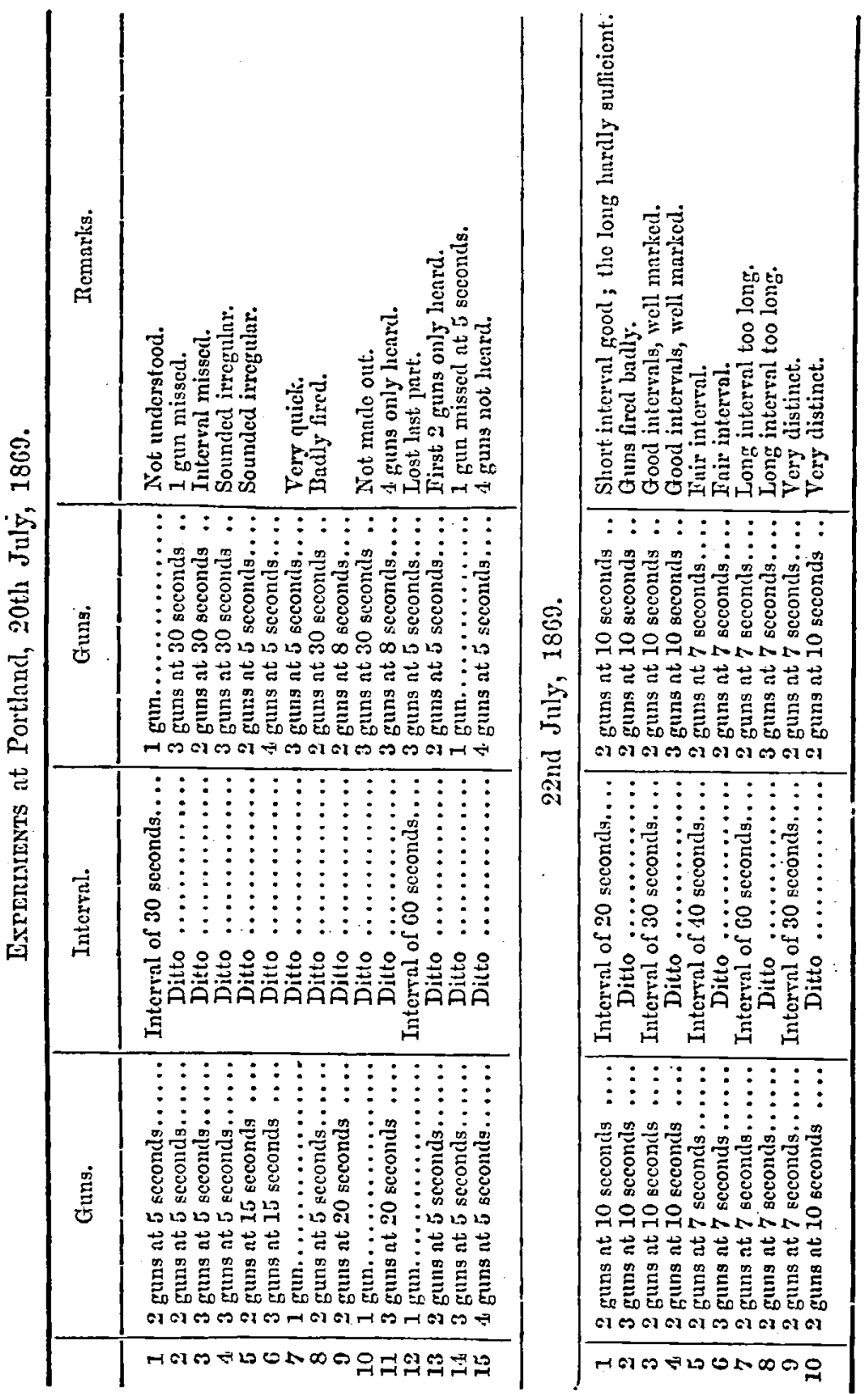
The result wo arrived at was that the 10 second interval was better thancither the 5 or the 7 , no guns being missed; also that the 30 second interval was so distinct a difference to tho 10 second interval, it was unmistakable, besides not being so long as to appear as if it did not belong to the signal made like the 40 and 60 second interval.

With gun fog-signals there is of course a limit, until some ono can invent a system whereby the firing of not more than 6 guns will givo combinations for many thousand signals, at the samo timo makiug each one so distinct that it cannot be mistaken for another. Provided the length of time in making the signal should be of no object, of course if 10 guns could be used, any number of signals might be made, but the difficalty of the number of guns is rery much increased now with the broadside and turret ships, those composing our fleets, as they carry but few and heavy guns, which guns should be used when possible; if not possible, the boat guns must be substituted. The principal signal makers in a fog, the flag ships, can use the guns they have for saluting purposes, which, taking into consideration their being used in a forg, ought to be 32-pounders.

After the experiments at Portland, Charles Brewer, the chief signalman of Her Najesty's ship "Ninotaur," gare me a scheme for gun for-signals, which I think the best I lave met; taking the intervals wo agreed on, he applies them rery simply in the following way : all guns to form a number to be fired at intervals of 10 seconds apart, but in the case of a double number like 12 or 5.1 , the interral between the integers to he 30 seconds. As an example 23, two guns with 10 seconds between them, an interval of 30 seconds and then three guns at intervals of 10 seconds, so that on hearing tho guns a signalman can count 1, 2, these being fired with 10 seconds between; he then finds a much longer aud well-marked interval, waits, and counts again $1,2,3$, having also 10 seconds between, and knows the signal to look for is 23 , turning to it at once. The great advantage of this is that the number of guns fired, gives tho number of the signal made; now, in the present arrangement, one of the greatest difficultics, really I think the worst part, is that the number of the guns fired gives you no clue whaterer to the signal made, that is to say No. 3 signal may be mado by firing only two guns, No. 6 by three guns, No. 5 by four guns, No. 7 perhaps also is made by firing four guns, of course at difierent intervals to No. 5 . Nos. 8 and 12 may both be made by firing five guns, hence the number of the guns fired, gives you no key to the number of the signal made, and the difficulty is so great, that it is no common thing for there to be many opinions as to the actual signal.

As I said before, there being a limit to the number of guns to be used-otherwise with 10 guns by Brewer's scheme any number might be made, provided the elenent of time was of no consequence- the number of guns and time being considered, firo was taken as the largest number that should be used. Practically five is a large number, and all signals having the fivo in them should be those seldom necessary. 'The following numbers are composed by five, 1 to 5,11 to 15 , 21 to $2 \bar{j}, 31$ to $3 \overline{5}, 41$ to $4 \overline{5}$, and $\tilde{5} 1$ to $\tilde{5} \overline{5}$, giving 30 signals in $\mathrm{all}$, against, 1 think, the $1 \pm$ or 15 now in the signal-book. 
To mako any of these siguals three guns at least are necessary; with the 12-pounder breech-loaders with which the experiments were mado at Portland, two wero sufficient, but with the larger broadside guns, four at least would, I think, be found requisite.

In dividing theso 30 signals, 1 to 5 should bo tho important ones made under somewhat different instructions to the other's;

\section{1 to 15 relating to altering course; \\ 21 to 25 to steam; \\ 31 to 35 to tacking and wearing; \\ 41 to 45 to hauling to the wind; \\ 51 to 55 to bo left blank.}

Of course in selecting 30 signals for use in a fog, ont of the thousands in the signal books, there will be much difference of opinion in a service like the Nary; but the necessary signals can always be arrived at by taking the opinion of the well known best Officeis. I merely put theso in as simply my own idea, to show tho way I think the 30 signals might be divided.

Of the present few fog signals, it is quite time that some alteration were made. They wero first selected for sailing fleets, and havo been handed down with but very slight additions, and although perfectly sufficient for a fleet with the wind as the only motive porrer, and therefore as the wind is generally light in a forg, obliged to move very slowly and naturally likely to kcep together, yet the caso is quite altered as regards a steam fleet, something more being required. Even in tho signals themselves, some aro annulled by Act of Parliament, two still remaining to distinguish tacks, - $n$ system abolished,-sailing ships being ordered to use a fog-horn, steam ships tho steam-rhistle, and ringing a bell distinguishing ships at anchor:

Time being an important element in the making of gun for-signals, having fixed on the period to clapso between the guns fired, it is now necessary to fix on the period between the repetitions of the signal, and also between tho different signals. There must always be a doubt of the bearing of a noise heard, especially when it is on either beam; ahcad or astern the range is narrowed, therefore the leaders of columns only should repeat. This order of repetition is laid down in the present signal book, and one cannot do better than adhere to it; the guns to form a signal always to be fired from the same side, otherwise somo guns might not be heard. The leaders of columns to repeat in the order of their divisions, allowing two minutes to be left between the last gun of the signal and the first of the succceding repeater, should four minutes elapse without a repetition, the next in succession should repeat, and after the last repetition, four minutes to elapse, and then the signal to be carried into effect.

Ifaving made a gun-signal in a fog; fresh signals should not be made too quickly, and unless actually necessary, gencrally spcaking, ten minutes at least should be left from the last gun of one signal before the Admiral commences another. All the times mentioned both for firing the guns, and between the repeaters, should bo the subject of: much care, and be-conducted with the greatest regularity, the firing 
would then catch the ear at the right moment, causing no uncertainty as to the number of guns fired.

I mentioned, when selecting the numbers of the signals to be mado by the five guns, that, 1 to 5 should como under somewhat difierent regulations to tho others, I will now talie ench one separately. No. 1, or one gun, to bo Admiral's position, and answer to signals made, Admiral's answer I mean corresponding to the aftirmatise by day; this signal requires a note to say that the Admiral will firc his position-gun immediately he is overtaken by a fog, and after that, at the hours and half hours during tho fog. In the present book there is a dificulty about this position-gun, for this reason I would put in the note. As it stands at -present, it orders ships to continue under the same sail, but is only ordered to be fired every half hom, one Admiral fires his first gun half an hour after tho fog commences, and continues to fire it at half hours from that time; another will fire his first gun with the first bell that strikes after tho fon comes on, and continue to do so with each bell; a third fires immediately he is enveloped in a fog, then perhaps at half hours from that time, or perhaps when the bell strikes the hours and half hours-as I think it should bc, and have in consequence put in the note. These differences of opinion aro very bad, especially on this signal; the half hour gun being the main guide to the fleet, they are following their Admiral.

No. 2, wr two guns, with the ten second interral between them to bo the preparative, which preparative is to be made before all signals, except 1 to 5 . One of the greatest objections to the present arrangement is that there is nothing to call attention; the lirst guns heard, though called preparative guns, not only being a preparation for tho signal, but also the signal itself, having to be counted as a part of it. and boing fired at the quick saluting time of five seconds, are continually being missed, and the purport of the signal is entirely changed. No. 2, the preparntive, should stand alone, made and repeated in order by the leaders, two minutes after the last repeater the signal itself of which it has been the preparer, should then be commenced, every ono would be on the qui rive, no noise, watches ready, and the signal with such elements of success, be taken in without doubt or hesitation.

No. 3 , or threo guns, at intervals of ten seconds, to be a signal to denote having shoaled the water snddenly; it can be seen why the two former need no preparntive, and as this would principally be made by a private ship to the $A d$ miral, who would answer it with his one $g$ un, it would of itself be so out of the common as to cause immediate attention being paid to it, and indecd would be the only gun signal I would placo in tho book for a private ship to make.

No. 4, or four guns, at interrals of ten seconds, would also bo better without the preparative, and should be entered as "Anchor instantly", this signal to be carried out inmediately it is heard. Whenerer it might becomo necessary to anchor a fleet in a for, if you knew where yoil were, the signal should not be made until the right moment; if suddenly in soundings, the siginal would bo made and carricd out immediately they wero heard by every ship. Ships in a fog are not soing very fast, especially in pilot water, they can almost instantly 
drop their anchors, and should then conmence to strike their bells as ordered.

No. 5 I would leare blank for filling in as senior officers may deem necessary while in command.

Although I advocate the advantage of a preparative before making fog-signals, yet the last three signals, following No 2, the preparative, as they do, would, I think, be so different, requiring different action, the advantage of having them would be lost if they had to wait for the preparative, with all tho time that must be passed in consequence; I therefore leave them by themselves, adding, they shonld be repeated as necessary.

Regarding the answering of gun-signals; hitherto the answer to most of the signals has been muskets in quick succession after the signal has been complied with. 'This is really no answer at all, besides muskets are not lond enough to be heard. Others had to be answered by denoting the tack a ship was on, when the different tacks were ordered by Parliament to be distinguished, so that I take it the answers to signals were practically nil. In my opinion there should be no answer to gun fogsignals, for if made with a preparative, and with a given time for carrying out the signal, the fewer the guns fired, the better. In a large fleet with only three repeating ships, if every ship fired a gun in answer-remember a gun is the only noise that can be heard from one endrof a line to the other-it would lead to such confusion, that it is better to trust entirely to the care and vigilance of those in the ships, than for the flag ship to be in an uncertain state of worry and excitement as to how many ships have or lave not answered, and perhaps hesitate in performing what she had already ordered to be done.

As at present there is a limit to gun-signals, something is required in addition, for of the many thousand siguals necessary for day aud night, surely thirty will not be sufficient for all the exigencies of a fog.

This want cau be supplied by the flashing-system applied to sound, using the steam-whistle, fog-horn, or bugle, enabling both general and rocabulary signal-books to be used intact, making as many signals in a fog as in clear weather.

Since the establishment of the "flashing-signals" by Captain Colomb, the harbour fog-signals, made in the same manner as the fog-signals for sea, have been entircly superseded by the use of the fog-horn on the flashing principle, and at sea it has been used at times on tho steam-whistle and fog-horn; but there are no regulations as yet except such as $\Lambda d m i r a l s$ in command of squadrons havo made from time to time, and lately $I$ have not seen the system so much used in a for as in Sir Sydney Dacre's fleet, between 1863 and 1865 ; it is, howerer, a firm basis for fog-signalling, and should be carried out to its full extent.

We require, however, a more powerful noise than we have at present. The steam-whistle is not good enough, the fog-horn, or bugle not loud enough for a flect at sea. The steam-whistles of all the marine engines I had crer seen, except high pressure boats, having been failures, generally commencing with a rush of water and ending in the faintest 
possible scream, I made enquirics amongst engineers and enginemakers about the steam-whistles of our engines, as to why they were so bad? I found that as a rule they were not mado as carefully ns the delicate parts of the engine, but that it had been found out by somo careful experiments that the distance from the cup to the dome must be in proportion to the diameter of the whistle; when made very carefully a powerful scream could always be obtained.

On my writing to Messrs. Penn, the engine-makers at Greenwich, saying I wished to find out the best steam-whistles, they vory lindly lent me two for trial, one with a sharp scream, and the other with a deep tone; these 1 had fitted to the steam-whistle pipe of the "Bellerophon," and although water as usual came up first, still I was satisfied the deep toned one was the best.

Captain Goodenough, of the "Minotaur," one day pointing out to me a notice in the "Engineer" of a "Steam-Roarer," by J. Bailey and Co., Albion Works, Salford, Lancashire, I wroto to them, saying I was making some experiments, would they lend me a "Steam-Roarer" for" trial ; this they most kindly did, I had it also fitted, but in consequence of the pressure in the "Bellerophon's" boilers being very much reduced there was not power enough to develop its use, but trying it on the steam launch's engine in Malta Harbour, it produced such a screan as to startle every one. The chief pecularities of Mr. Bailey's "SteamRoarer" may be described as follows :-

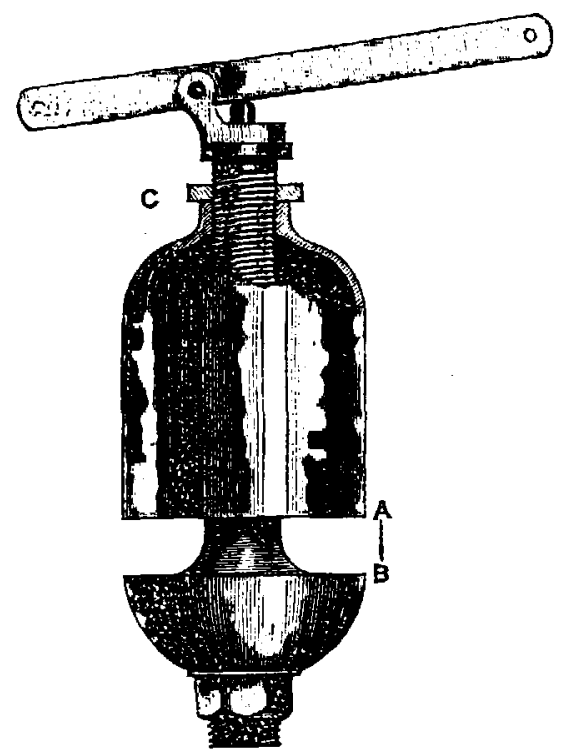

1st. The latest one is adjustable, and can be made to exert its highest power, for either high or low pressure steam, if used on a hoiler with 15 lbs. pressure, lower the dome and diminish the distance 
from $A$ to $B$, and increase tho distance as greater pressure is used. Altering the distance from $A$ to $B$ is done in a simple manner, by loosening the lock-nut at $\mathrm{G}$, and turning the dome round.

2nly. Tho stean-way of tho instrument is larore, and instead of using a cock or plug tap, a full-way inverted ralve is used, which is kept tight by the pressure of the steam, and the moment it is opened, the full pressure is on the instrument. By the peculiar lever arrantrement on the top, a weight may be placed at one end, so that if necessary to fis it at any height the weight will closo the ralvo on censing to pull at the chain or wire.

3rdly. There are very fow parts in this instrument, and it is not likely to get out of order:

Since the "Bellerophon" paid off, I have been in communication with Mr. Bailey, telling hin what is wanted, the result is the instrument just described, which, after being adjusted for the steam pressure, makes the sound as loud at first as at last, and is the very thing wanted for flashing-siguals in a fog; it is used in some rrerchant steamers, and I hopo MIr. Bailey will soon have it tried in the Channel Flect.

There is yet, eren with good steam-whistles, something to be done with the pipe from the boiler; the opening valve should, 1 think, be close to the boiler, instend of the whistle, but the handle still to be on deck, and there should also be a small cock for letting off any water there may be inside the pipe frum condensed steam.

To be able to make flashing-signals on the fog-horn, Captain $\mathrm{M}$ Iay, in the "Northumberland," the other day hit on a very ingenious plan. Ho had the steam launch's boiler filled with air by the air-pump of the diving apparatus, getting easily $15 \mathrm{lbs}$. pressure, and more if necessary; lo then fixed on a fog-horn, and was able to get a good loud sound, sharp and well defined.

It will be seen by this that, having got the "flashing-system" for signalling, people require a good instrument to make the siguals; and as some are turning their attention to it, I have no doubt ere longour ships will be able to communicate with ono another in this manner easily from one end of a flect to the other. Flag ships in particular oughit to be first of all well fitted with stearn-whistle or roarer, and foghorn. In making a flashing-signal in a fog, it can bo used cither by itself or in conjunction with a gun-signal; in harbour it should only bo used, the ships being much closer together. $\Delta$ t sea all signals from the general and vocabulary sigual-books, except the thirty selected for gun-signals, should be mado by the flashing-system, and when good instruments are supplied, an Admiral may make sure his signals aro as rell understood as if inade in clear weather with flass. When the Admiral makes a flashing fog-signal, ships nearest to him should answer first, the rest in succession, repeating for safety, all signals from the general signal book, and answering only all siguals from the vocabulary signal-book. Should a ship notice that her next astern, does not answer, she should repent again, if necessary with her pendants. The leaders and regular repeating ships of a squadron need not repeat "flashing-signals" except in the manner just mentioned. If the squadron 
is in a single column, it is a very good plan to repeat the signal, whatcrer it may be, down the line, and then repeat the answer from the sternmost ship back to the $A d$ miral ; by that means the Admiral knows that all the ships understand his signal. These signals should bo governed exactly by the same rules as "flashing"-night-signals," but in case of ordering an erolution, for commencing which at night the Admiral shows position lights, or burns a short signal-light, ho should in a fog;, when all ships havo repeated, firo his position gun, then, four minutes from that tine, the evolution is to take placc.

By the Order in Council for "Preventing' Collisions at Sea," sounds on the fog-horm denote being under sail, on the steam-whistle being under stcam, and ringing tho bell being at anchor. Nothing is laid down ns to the particular sounds to be made, so those most conducive to order and safety can be used. At present it is the habit for cach ship to sound her pendants on the flashing principle; but as slips wish to communicate by the same principle, thero is a difficulty. According to the rules, the ship nuking the signal has to commence and end her signal with the pendants of the ship spolien to, causing some confusion to other ships, which might only hear the pendants part of the signal. And in case of ships in different lines signalling to one another, it would exnctly seem as if they liad changed places, the ships astern or ahead of each, would at once think thoy had by some unaccountable means got over to the other line, and if commanded by anxious men, try, as thcy thought, to lark back; they would get hopelessly involved, and unless the fog lifted, would end in their losing the flect altogether.

If my meniory does not fail me, when the late Lord Lyons took one of the Kerteh expeditions, I think the second, with the Turks embarked, we were all one day in a fog; and the few large ships in the little squadron ringing their bells, struck the number of their seniority, the Admiral's ship striking 1, the "IIannibal," 2, the "Algiers," 3 , and so on. This struck me as being such a good ray of distinguishing ships in a fog, that I would direct ships in a fleet in a fog, whether they uso steam-whistle, for-horn, or bell, always to sound their flect numbers; by this means, while acting in accordance with the Regulations for l'reventing Collisions at Sea, there would be no confusion in maling another ship's pendants when wishing to communicate.

It is a matter of some importance to be able to communicate freely with another ship in a fog. In the "Bollerophon," in August, 1869, with one of Messrs. Penn's steam-whistles, lent to us, wo were able to find out from the "Iercules," at least 10 cables off, the direction of the Admiral, and although not in his line, we casily picked up tho wake of our next ahead, tho "Northumberland," which ship had fast hold of the leader of our line; thus when the fog cleared off we were in our place.

There is one case, however, in which I think special sounds on the fog-horn or steam-whistle should be laid down, and that is in passing from one tack to another, whether under sail alone or under steam and sail. It is then more important to know what tack an approaching ship is on, than what particular ship she may be ; directions should be given thatd uring this evolution only, ships on the starboard tack, should make a series of long sounds, and slips on the port tack, a series of short 
sounds, referring back to their flect number when the evolution is over, of course using the fog-horn for sail only, and the steam-whistle when under sail and steam. By these means I think perfect signalling may be maintained in a fog. There should also be some instructions that Officers may not only easily find out how the "fog-signals" will be made, but also what they hare to do in a fog themselves. The Order in Council for "Preventing Collisions at Sea" being paramount, its directions must be carried out in the signal-book. The speed is laid down by the Order, and is not to be more than from three to four krots. It is a safe speed, as it enables a ship to stop easily and quickly, and should of course be used under ordinary circumstances; but in the exigencies of onr naval service, it may often be necessary for a fleet to proceed faster, and amangements must be made in order to meet a greater speed. It should also bo laid down when the Admiral will reduce speed if going fast at the commencement of a fog; should he even wish to continue at the same speed, it would be better as the for came on, to fire his position gun as directed, and four minutes after the last repeater, reduce to the regulated four knots. The fleet would then closo up, and by steam-whistle he can state the speed, or the number of revolutions he intends to proceed at, but under ordinary circumstances, of course the fleet is bound to proceed at the laid down speed.

Whenever there is appearance of for and it is practicable, the fleet should be formed in single column in line ahead, and in close order.

Firstly. Because in line ahead there is less danger of fouling.

Secondly. Station in a fog can be so much better hept in line nhead.

Thirdly. Signal communication can always be kept up, and

Lastly. The fleet can go at a greater speed if required than four knots, with more certainty of keeping together.

The most easy position in which you can bo placed at sen to keep clear of another ship, is when coming up astern, whether in day time, at night, in a fog, or thick weather. This, I believe, no one can gainsay; by putting the ships in single column in line ahead, all ships are coming up astern of one another. Kreeping station in a fog when in line ahead is always much ensier than in any other formation, for the reason that eren in so denso a fog the ship ahead canmot bo scen, as there is generally but little wiud and smooth water, the very wake of the next ahead can bo seen and steered in. By putting the ships in close order in line ahead, there can be no doubt on the part of the $\Lambda$ dmiral that all ships in turn understand his signal, and should a ship be missing, which would be known by her not repeating or answering the signal made, it can bo reported to the Admiral by her next ahead; this will give him greater confidence if ho wishes to alter course, increase or decrease speed.

The single column formation, laving all the above adrantages, enables the flect to proceed at any speed that may be necessary for the fulfilment of orders; that I am not adrocating this without experience, I must relate an incident in the life of the Channel Fleet.

In September, 1865, when that fleet was commanded by Sir Sydney 
Dacres, on its ray from Spithead to Bantry Bay, a little outside the Nab Light,-Deing then formed in single column in line ahead,the ships became enveloped in a for. It was in the evening when this fog commienced, lasting nearly 36 hours, the Fleet steamed down channel at more than 5 knots speed; one ship was known to bo missing before the fog lifted, and when it did lift, the ships, with the one exception, were in their stations. Signal communication had been kept up the whole time, and no land was seen from leaving. Spithead until the MIizen Iread was sighted on the coast of Ireland. The easy and admirable way in which the "Mector," next astern of the "Edgar" kept always just in sight, I shall never forget; at times she was within 20 yards of her leader's stern, and then would drop until almost out of sight, but with pride those in the "Пector" may, I believe, say, they never really lost sight of their leader in that fog.

It is, I think, a wise precaution that during a for, the fleet if under sail, should always maintain the same order, and continue on the same tank as when the fog came on, even if the wind changes its direction, until it is ordered by signal to do otherwise; this removes any question of doubt that might arise in the minds of officers in command of ships; also in the case of a breeze springing up after a calm, which would prevent the fleet proceeding as before; the $\Lambda$ dmiral would first come to the wind by signal, on the most advantageous tack, and then, if tho wind be iavourable, after he is sure all the ships are on the tack ordered, keep away to the course intended. This seems a roundabout way to get to a certain course, but as to all ships when under sail a certain number of points are shut, on the principle of "the longest way round being the shortest way home," it will be easier and safer for all ships to get on one tack first, and then bear away to the required course in succession. In tacking under sail in $a$ fog, great care will have to be taken, in noting particularly the time of the last repeater, making sufticient sail to ensure tacking, and then in reducing sail again as soon as about, so as to proceed at the proper spced, and to signal carefully the tack the ship is on. Although in a fog, such fow evolutions as may be performed, should be carefully carried out, as laid dorn in the sigual book.

I speak of evolutions, but am perfectly aware they must be of the most simple description, and of such a nature as to cause the least possible risk to the ships in their performance; care should be taken to make them successive, and not simultaneous, for the reason that risk of collision is lessened when following a ship. What the evolutions actually should be, must depend on the signals at command and the circumstances of the case; it is a subject on which no rules can be laid down, but must be left to the ability of the $\Lambda$ dmiral, aided by the intelligence and activity of lis captains.

On a ship of the fleet discorering any danger, she should immediately fire guns in quick succession, and if necessary to make a movement to avoid the danger, she should fire a position-gun at intervals, to show how she is standing to avoid it; if a ship should actually strike the ground, vesides firing guns while ashore, she should also fire rifles, bent drums, sound fog-horns or stean-whistles, making all the noise 
she can in fact, so that every one may be attracted by her unusual proceedings, and avoid closing nearer the sounds heard.

In case of it becoming necessary to anchor a fleet, as the ships drop their anchors they should strike their flect numbers on their bells, and continue to do so until all tho fleet has ancliored.

After all it will be seen that 1 advocate no new principles in the "fog signals" for the Navy, but believing that those now in use, have certain shortcomings, and are not sufficient for the wants of the present day, and having noticed that as the matter stands, the signal staff of ships appear to partake of the nature of the surrounding atmosphere, never seeming quite clear, for what they should look out $-\mathrm{a}$ gun being fired, causing them berrilderment-also, having seen Officers turn to the signal-book expecting to find everything ready to their hand when in the fog, I think the Nory requires a very clcar and simple "fog-signalbook." Of course both Olficers and signalmen should know the "fog" as well as other signals in use; when they do not do so, they feel their ignorance, and are in consequence wanting in that solf-confidence which ensures promptness of action. This evil is lessened as the signalbook is clear and simple, but it is much increased as the thing stands at present, there not being clear and concise information of what is to be done and how ships are to act; and on any run-signal being made, particularly from the quickness of tho guns fired at first, there is very often some difference of opinion as to the actual number fired, and therefore of the signal made; in consequence Officers in command fear to make a decisive movement, the fleet becomes scattered, and if the for lasts, some ships are missing at its close.

Adrocating no new principles, nothing is required except that the old signals should be simplified, modernized, and extended, and the "flashing-signals" ordered to bo used.

I would add a few more instructions, and think it would be a benefit if the signal book stood thus :-

1. Instructions relating to fog-signals.

2. Instructions for the conduct of a fleet in a fog.

3. Gun-fog-signals.

The instructions relating to "fog-signals" should describe and direct the different methods of signalling, commencing with the gun-signals as the most important, and ending with the "flashing-siguals" by the steamwhistle, bugle, or fog-horn. Tho instructions for the conduct of a flect speak for themselves; in them I would embody all that I have before stated, to enable a fleet to keep together howerer long a for may last. The "gun-fog-signals" should indicato somo few selected signals, learing all else to the "flashing system," pre-supposing erery care lias been taken to furnisin the ships with the best instruments.

No fog-signal books are complete without one of Admiral Ryder's markers; a small board with two divisions, in each division holes, and a pers at cach end, the first or left hand division marked "Preparative guns at five seconds," the right hand division marked "Signal guus at thirty Eeconds." 
For every gun hearl at the marious intervals, you place tho peg in a hole, and when the signal is finished, you have the number fired

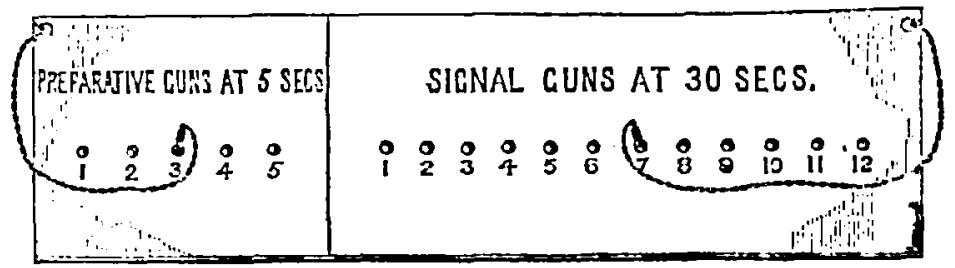

beforo you. This board can bo mado on board any ship, and should bo kept in tho bridge-house; Captains will find it useful to keep one hatudy in their cabins. Whatever interrals may be fixed on, can always be adapted to this marker, with what I propose, the bonrd would be in three divisions, the riglit and left with holes for the "guns at ten seconds," and the centro being merely marked "iiterval of thirty secundls."

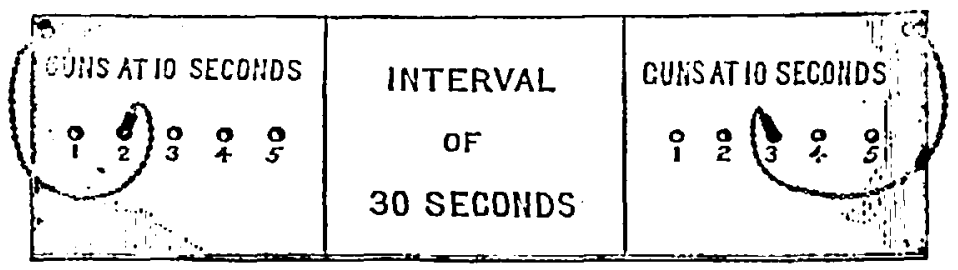

After the signal is nade, with this method, you would see before. you the yumber of the signal to tum to, instead of having by the present arrangement to look through all the signals to see the nunber that has been made; this is perhaps a small matter, hut it tends to settle the rloubt of how many guns have been fired, and gires confidence to carry out a signal.

Whaterer fon-signals may be established, and there has been a committee lately which will shortly give the service the results of its labours, no books or systems are of much use unless the forg-signals are practised when the fleet is not only in harbour but at sen.

I hear in future that the siguals for a fors are no longer to be called "fogr-signals," but " gun-sigurls," to let people know that they need not necessarily wait for a for to use them; this is an exceedingly grood idea, is it will teud to fumiliarize sigualmen with this means of signailing. To exercise the "for-simnals:" the $A$ dmiral shonld inform the fleet what he is alout to do, making not only gun but flashing-signals, and overy ship should send in to him on paper" what they had taken in; this would precent the startled efiect a "forr-signal" now produces.

IIowever perfect a signal-book may be made, there is a part which may be called the seamanship of the question, which cannot be laid down, but must le left to those in charge of our ships. I an quito arrare that in is for suddenly coming over a flect, great caution wust 
be displayed, and the most vigilant look out kept, but I do not think in a well-ordered service, with the means now-a-days at command, a fog should cause tho slightest fear or hesitntion, all should know exactly what to expect, the system and modes of signalling to bo employed, that the movements ordered are imperativo at the right moment, that on seeing one of the fleet, she should never be lost sight of again, however close it may be necessary to hug her, and that it should be the pride of every one to emerge from a fog in exactly the same order as they were in when it enveloped the flect.

The question of ships keeping close to one another when seen in a fog, being one of the matters of seamanship, can liave no direct orders in the signal-book, and is left to those who may have charge of ships. There is no hint even of closing on your next ahead, and the tendency is rather to go slowly and open from her, indeed I have often noticed a decided desire on the part of Officers to get awny from and lose sight again of any ship that might approach near enough to be seen. T'inis ought not to be, as the ships are under steam almost as a rule in the large squadrons. As fogs principally come on when the wind is so light that the ships are quite unmanageable, they generally cruise with fires banked, if 'not regularly steaming at the time; erery Captain therefore would immediately have steam ready, so that in treating of a large flect in a fog, it may safely be presumed it is a steam flect. It was in a steam flect that I noticed the desire to open from anything secm, instead of hugging close the next ship, and as sho can see a little farther than you, it may at least be hoped that she sees another ship of the squadron, and so on. I hold that there is never an excuse for a ship getting a way from her next ahead; the rery wake of a ship can be scen and steamed after in confidence, and no ship of a line, ought erer to be out of the line, however long a fog lasts. The other part of the seamanship question consists in the care taken on board the ships; the look-out should be vigilant, gencrally low down, but it is as well at the same time to hare a man at the mastliead. I lave known instances when the mastheads of other ships could be seen from aloft, and sone when a man slung in a borrline close down to the water could see their hulls. There should be more than one look-out man, and the water should be carefully looked at, as it enables you to sce if you are following a ship. Perfect silence should be kept on deck; if any of the ship's artificers work there, they should cease in their work; as many of the signal staff as possible should be on deck, one of them with the fog-horn or by the steam-whistle; and a carcful Officer be ready holding' a watch with a second hand and the marker, to note the guns and the intervals at which they are fired. The speed should be carefully attended to, and if under steam, the engineer officer of the watch warned to stand by his engines as the ship is in a fog. Abore all I would impress on every one the great necessity the instant a fog comes on, or better still if seen coming on, to close on the next ahead, and having once caught sight of her, if it entails the jib-boom literally over her stem, never once losing sight of her again, stick to her; it is right in the first instance to allow nothing to throw you out of your place in a fleet, it is creditable to preserve it under all circumstances, and it gives a confi- 
dence and pride in the ship to all on board to see that whatever happens, she emerges from the trial, in closo contact with her consorts. These are things which no signal-book can lay down, they rest entirely on Officers, on whom lies the responsibility that the fleet shall not got scattered.

Before concluding, let me read to you a summary of fogs reported from Penzance, Plymouth, Portsmouth, and Yarmouth; for the years 1868 and 1869. Writing to MIr. Robert Scott, M.A., of the Metoorological Office, on the subject of fogs, he most kindly had copied out and sent me the wind and weather log, when fogs occurred during the two years abore mentioned. From this $\log$ I am able to give you the following :-

There were-

\section{In 1868}

At Penzance, 13 fogs.

At Plymouth, 17.

At Portsmouth, 7.

And at Yarmouth, 9.

Of these the following numbers occurred during calms:-

At Penzance, 3.

At Plymouth, 13.

At Portsmouth, none.

And at Yarmouth, none.

The greatest force of wind in these fogs was-

At Penzance, 7 , with an average of $2 \cdot 9$.

At Plymouth, 5 , with an average of $\cdot 5$

At Portsmouth, 2, with an average of $1 \cdot 2$.

And at Yarmouth, 3, with an averago of $2 \cdot 6$.

The months of January and Norember had each 7 fogs between the abore places, but in Mray none were reported from either place.

The fogs in $1868 \mathrm{secm}$ not to have been of many hours' duration. There were fogs reported of $2,3,4$, and 5 hours, but only one of 24 hours, at Penzance, on the 7 th March. Besides the above times, it was twice noted as foggy in different parts of the British Isles.

There were-

In 1869

At Penzance, 23 fogs.

At Plymouth, 31.

At Portsmouth, 12.

Aud at Yarmouth, 19.

Of these the following number occurred during calms:-

At Penzance, 3.

At Plymouth, 19.

At Portsmouth, 9.

YoL. Xr.

And at Yarmouth, none: 
The greatest force of wind in these fogrs was-

$\Lambda$ t Penzance, 6 , with an averngo of $\mathbf{2} \cdot \mathbf{3}$.

At Plymouth, 2, with an average of 5 .

At Portsmonth, 2 , with an averige of 3.

And at Yarmonth, 5, with an average of $\mathbf{2} \cdot 2$.

Thero were 20 forrgy day's in Novemler, but Mny and June harl only two foggy days cach, between the aboro places. 1869 may bo takeu as a very forgs year. 'Tho longest for occurred at Penzance, commencing at 7 p.m., of the 9 th Oetober, and lasting until 2 p.m., of tho 12 th; 67 hours with no wind at its commencenent, the wind gradually freshening, until it was registered 3 at the fog dispersed. Penzance had besides this, on the Sth and 9th of April, oue of 48 hours; on tho 11 th and 12th of $A$ pril, one of 36 loours; on the 16th of July, one of 24 hours; on tho 8th of July, uno of 12 hours; and on tho 18 th July, another of 12 hours.

Plymouth had on the 15th March one of 10 hours, and on the 11th of October, one of 24 hours.

Portsmouth had one long fog, on the 18th and 19th of November, of 38 hours, otherwise the fogs were not so long.

Yarmoutli had, on the 7th and Sth of January, one of 31 hours; on the 21st and 22nd of January, one of 31 hours ; on the 28th and 29th of January, one of 36 hours; on the 18th and 19th of November, one of 22 hours; on the 25 th and 26 th of November, ono of 33 hours; on the 28th and 29th of November, one of 81 hours; and on the 10th of December; ono of 10 hours; beside the above times thero are twelve notifications during the year of fog being prevalent at times in parts, and at others over the whole British Isles.

It may be said I have mado too much out of a small matter, bringing forward nothing very now, and that in spite of such fogs as I have just read of, no accidents can bo remembered that have occurred amongst fleets in a fog;, although "for-signals" have for many years formed so small i part of our signal-books. I grant all this, but knowing that some Officers have been wishing for something more in the way of "fog-signals" than we have at present, and that the means of communication between slips in a for lave improved, I have turued my attention to the matter, and think the alterations I should like to see made, if compiled and issued to the service, would be an advantage; at the same time in point of printed matter, there would be very few pages in excess of that now in use, while, for simplicity and usefulness, the service would be the gainer.

Let me ask you to turn your attention to the great war now raging on the Continent, and we sec that the couquering power has been the oue that I may say, has descended to small matters; everything is arrang ed, even to the most minute details; not a thing forgotten, and by this rery means the German mation has ascended to a porrer and might unparalleled in history. Belonging as we do to tho greatest maritime uation, we must not let the lesson pass us, but enter into all minuto points, see all small matters as well arranged in their way as large; for a fog might some day prove a very serious matter to us. 
Let me put a case: two squadrons, from two different naval ports, are required to meet as day breaks at some appointed spot, ready to striko a necessary, well-timed, and effectivo blow at an enemy; one of theso squadrons encounters fog; and by not being well instructed and prepared for such a thing, goes slowly, perhaps stops, aud ends in becoming scattered, with some ships missing. This squadron cannot arrive at the proper time, and the operation is worse than useless, for your opponents havo seen something of your strength and strategy; or tako a case worse still, viz., that of a squadron sent in haste to prevent somo attack on ourselves, through being scattered in a fog, arriving at its destiuation too late. May tho fall of the great military power of France, considered until now the first in Europe, and corresponding to the naral power of England, bo a warning to us that we cannot take too much trouble with our Navy in all its points.

Admiral Lord Fnederick KenR: May I ask our friend if he knows the duration of the for which ho alluded to in 1865 .

Captain BRENT : About thirty-sir hours.

Iord FREDERICE Kerle: I happened to bo in that fog, and I should liko to mako an obserration in confirmation of what Captain Drent has said, or rather to enlarge upon the point. Fop remarked that the for fell upon the ships after rounding the Nab, when they were in single line, I think. The flect uas in single line, haring left Spithead with a bright sunny sky. It was one of the most beautiful days erer eeen; jachts were sailing about in all directions. No signal had been made for rendezrous, as we had been sent to sca under sealed orders, not knowing our destination or rendezrous. We Ieft in line-of-battle, the lce column, or port dirision, being in rear of the starboard dirision. There were sir or seven ships, and we trero about three miles from the Nab, haring just passed through St. Helen's, when the fog fell suddenls on the ships so thickly, that we could not see the nest slip ahead. It was then a critical time for the use of for-signals. We had to judge our distance, and the right moment for rounding the Nab, for we were going down Channel. No signals had been made for renderous. The difficulty would have been lessened after rounding the $\mathrm{Nab}$, and I may mention this to point out the circumstances in which signals might be adrantarcously used. I was the leader of the lee line, consequently $I$ was in the centre of the line when in line-of-battle. When, as we con. cluderl, we had reached the $\mathrm{Nab}$, and it was about our time for rounding, it was reported to me that there was a whistle on the starboard bow. Gentlemen probably know the position; the $\mathrm{Nab}$ is on the starboard side, and tho whistle was on the starboard bow. We concluded it was the Admiral's whistle to signal that he had altered his course and had rounded the Nab. Accordingly, wo also altered our course, supposing twe were following our leader. The ships were about two cables apart when the fog came upon us, or perhups more. After altering course and proceeding in this direction for about five or ten minutes, haring rounded the Nab, the look-out man called out, "there's the splash of a screw on the port bow!" so there was something not very far off on the port bow; no other sound was to be heard. The order was giren to "easo;" at the samo moment I looked, and I saw the jib-boom of a ship plainly in the fog, just hanging orer our port quarter. By porting the helm in time the slip cleared us. We were at a loss at the time to know how we got into that position, but it turned out that the whistle we had heard was not the Admiral's, hut of some casual passing eteamer, and by iltering our course so much sooner than our leader, it led erentually to our cutting through the line between the Admiral's ship and his sccond astern. Having orercome thai difficulty, rery shortly afterwards occurred another circumstance which I will mention to sliow on the other hand tho adrantage which has been derired to the serrice from Captain Colomb's flashing signals as applied to steam. Wo had not then had any orders to practice with these signals, eithet with fog-horns or with steam. Somo experiments had been mado with fog-horns, but to the best of my recollection this was the first time experiments were is 2 
mado with tho "Flnshing Signal Code," by steam. Signal was made by the Admiral first to "form tro columns," and in the nest place to "rendezrous off the Lizard" (or off Scilly), and giring the course down Channel. 'The signal mas giren with the steam-irhistle, and it was repeated by ourselres as the leading ship of the other dirision. We formed the two columns, and we were hept together by 15 minuto guns, from the Admiral, repeated from the leading ship of the lee line, for we never ear anything of each other until we got down nearly off the Eddystone, going sis knots all the time. There was only one ship miszing, which had thought it right to leare the line and go in shore. I mention this to show how much tho serrice is benefited by Captain Colomb's signals not only in the night time in clear weather, but in their application to the steam-whistles of ships in times of fog.

Captain CoLorr, R.N.: I must express my regret that I did not bring down with mo a book which I intended to havo brought. It is the "Experimental Night and Foo Signal Book," which I belierc is now issued to the Channel and Mediterranean fleets for trial. In that book by far the greater part of Captain Brent's suggestions hare been adopted. The sugrestions werc, on the face of his reports, so absolutely necessary, and their necessity was pointed out so clearly, that the Committee, of which I was a nember, adopted the greater part of them without any dissent whaterer. But there were certain parts which were not adopted, and $I$ think the questions as to those parts still remain open. Captain Brent suggested that the best interval at which the signal guns should be fired was ten seconds between the first guns; then an interral of thirty scconds, and ten scconds between the second series of guns. The Committee, howerer, thought that as we had oniy those experiments before us, that we should not be justified in making a clange from the interral so long cstablished in the Nary. Ify own wish would hare been that further experiments should hare taken place, because the circumstances, as Captain Brent has pointed out, under which gun-signals are now made, are very diferent from what they were at the time those interrals mere established. We hare now to deal with ships such as the "MIonarch," with four heary guns. Those heary guns must be used for the "fog-signals," becausc, as the lecturer has pointed out, you do want the rery loudest guns you can use. It follows that it is almost impossible to conduct your signals at interrals so short as fire seconds, which, if my memor's does not deccire me, is still the established short interval. I think these remarks embrace nearly all that can be said on the spur of the moment as regards "gun-fog-signals." As regards "flashing-siguals" when used in fogs, I think nearly the whole of Captain Brent's suggestions were adopted in the Experimental Book. But I agree with him that that braneh of the subject is still quite in its infancy. I cannot doubt that it ought to be possible in these times to hare a sound flashing instrument, which would be capable of conveying signals between two columns, situated at their ordinary cruizing distance apart. As we stand now, when a fleet is in tro columns, thes aro cut of from one another; one column is cut off from the Admiral, exceptin respect of the few gun-signals which can be made. I see no reason why if inventors' nttention were sufficiently turned to the subject, we should not hare "flashing-fog-signals" capable of trarersing the distance between the two columns, and so beeping up that complete communication which is so necessary in fleets. I do not think that any naral Offeer will imagine that the subject which Captain Brent has treated of, is a small subject. To my mind the safety of the country may at anj moment depend upon a fleet being bept together in fogs, and being properly under command of the Admiral. And when one comes to think what is on the other side, what is against our haring a fleet so in hand, and so kept together, we shall sce that it is worth in. restigation. Practically, no expcriments in "fog-siguals" hare crer been tried, except those stated on the board before us. I nerer heard of any haring been tried myself, and I nerer nact with angbody who erer tried any "fog-signals." We gencrally say, "Oh, the thing lias answered rery well for so long, aud it will answer very well for so much longer ;" and we go no further in the matter. The history of the thing is that the fleet nerer gets into a for on any occasion without mistakes being made; and sometimes those mistakes lead to rery great misfortunes, such as the separation of ships. I cannot at the moment gire a case where this has lappened in fogs, but $I$ can gire a case whero it happened respecting the old "uight-sigaals." It became my 
business, when I was commencing the study of the subject, to find out really where it was that the old "night-signals" failed, because I thought when I arrired at that point I might know what was manted. Therefore I made it my business to go on board ercry ship in the Channel fleet whenerer I could, and whercrer I could. On many occasions I found that tho first answer giren to mo was, "Oh, there's no dificulty at all, the thing answers perfectly well." "There were no mistakes then?" "No." But I nerer found on any occasion when I pressed the question home, that mistakes did not occur, and that quite recently. On board the "Donegal," in Plymouth harbour, I went just after the Channel fleet had arrired. I said to the signal officers, "What about the night-signals-have you any fault to find with them?" "Oh, no; thes answered perfectly well." I said, "Don't jou know of any mistakes baring been made at all?" "No, none at all; they answered perfectly well." I said, "Let us look at your signal-log." Thes got the signal-log. I'said, "That signal, for instance," pointing to one made two days before, "was that right?" The answer was, "No, that was not right; it was a signal to get steam up, and we took it to be a signal to steer south-west, and we parted from tho flect in consequence." The fact is, that in the Nary we seldom tabe note of mis. takes once they are passed; and until we cstablish something like systematic crperiments, such as we hare before us, we shall not succed in getting a perfect system of fog-signals, nor in fact suceced in getting a perfect system of any hind.

The Cinarryax: Before returning Captain Brent our thanks, I should like to make an obserration or two. In the tropics we rery seldom hare any fogs nt all. The fogs are confined rery much to the Channel, the North Sea, and the Baltic; although of course they occur elsewhere. It is only since the Channel Flect has become an institution that we hare thought much about the fors, at least in $\mathrm{my}$ recollection. Tro instances were mentioned just now as cases in point, wbero tho Fleet was in a fog a long time and was kept together. I can gire an instance whero we were separated in an hour in a fog. We were six or seren ships off Lisbon. A fog came on rery rapidly. Signals were made by the Admiral to take the ships out of danger. The signals were so entirely misunderstood, that when tho fog cleared two hours afterwards, the Flect was scattered about in all directions. 'That was entirely owing to the guns that were used for for signals being quite incompetent. Formerly, we used to employ 32-pounders, which had a chargo of $6 \mathrm{lb}$. of powder, and with the $6 \mathrm{lb}$. of powder we could hear well from one column to the other. But these guns rere supplied with a clarge of 1 lb. 8 oz., at all crents so small a chargo that we could not bear them distinctly. It was with the rery greatest difficulty, by making ererybody quict, and by putting your liand to your car, that you could hear at all, owing to the blocks and ropes rattling about. I think the mistake arose from the guns being too small for the purpose. If we are to hare gun-fog-signals, wo must hare proper guns for them. In the case of ships with only a ferr guns of from 9 to 25 tons' weight, I beliere it will be impossible to fre for-signals, remembering that many of the gung in some cases consecutirely hare to be fired at fire seconds interrals. This is perfectly impracticable, especially as the guns must be fired on the same side of the ship, and with great accuracy. If we are to haro gun-fog. signals, guns must be supplied for the purpose, and they must hare charges of at least $6 \mathrm{lb}$. I believe that is at the bottom of the whole question. But to securo effectire signals, we ought to hare a proper screamer. At present the Admiral has no power to spcak to an indiridual ship, howerer much lie may wish to do so. I hare suggested a method by which the $\Delta d$ miral might with the gun-fog-signals ascertain how many and which of his ships, if any, are in company with him, and the approximate bearing and distance of cach. At the cnd of say erery two hours, riz., at two, four; six, eight, ten, and twelre, let the Admiral, if he wishes to ascertain the position of his slips, fire four minutes after the half-hourly fog-gun the following gins, riz., two guns with a minute interral. Each ship has now a feet number, the Admiral is No. 1, the ship astern of him No. 2, the leader of the lee line No. 5 if there are four ships on the weather line, and so on. Then if the ship whose lleet number is 2 fires her ansmering gun at esactly two minutes after the $\Delta$ dmiral's gun is heard, the ship whose fleet number is 5 , exactly fire minutes after the $\Delta$ dmiral's gun is heard, and so as the Admiral will, by the interral in minutes, know tho ship, by the direction 
of the report know her approrimate bearing, and by the number of seconds orer and abore the minutes know the approsimate distance for this number of ecconds; halred and multiplied by $4 \frac{1}{2}$ will gire the miles; in distance, the whole flect's position may be plotted on paper, although none can be seen. If, howerer, the Admiral wants to send a ship on any particular duty, or to call a small ship to lim, he has no means of doing so by the ordinary gun-fog-signals, for thes ouly speak to all the ships at once. If me had proper sereamer-whistles, the Admiral would be able to speak to any ship he likes, by long and short screams, as in the flashing-signals. The rcason why we cannot have eficient stean-for-signals is becruse the steam has not enough pressure. We hare only about 30 lbs. pressure; in a locomotire you hare $100 \mathrm{lbs}$. pressure, and then you get a good whistle. Until tre take the thing properly in hand, and hare something like a high pressure steam, or, what is mich better, compressed air acting under a pressure of $100 \mathrm{lbs}, \mathrm{I}$ am sure we shall nerer get a proper whistle to serre as a signal. ddmiral Inglefield's hydraulic engine juight easily, when fitted for stecring purposes, bo adapted for compressing air for fog -signals when requisitc. I beg to return our thanks to Captain Brent for his erecedingly instruetive paper.

The Cinsmsrax: Will you notr reply to the questions?

Commander BRExT: I think the questions lare been nearly all answered. The fog which I referred to lasted about 36 hours. I beliere if there had been an instrument like the stcam-rorrer in the fleet, there wonld haro been no difficulty in making ont ansthing; iny signal could lare been nade out. The thing is to get a good steam-whistle, something that will make a good scream. Mrr. Bailey's is the nearest to it that I have scen jet; it is much louder than any steam.whistle.

The Chairstax: The same pattern?

Commander Brext : It is the same description. I wish we could get some of these tried in the Channel Fleet; it rould soon settle the question.

Captain BozGess: Whint is the pressure required?

Commander Brext : You can use any pressure. I uscd $40 \mathrm{lbs}$. at one time in a sterm launch, and the sound was most startling. This was in Malta Harbour. But with the low pressure of $15 \mathrm{lbs}$. it was nothing. I agrce with what Captain Colomb las said about experiments. It is a pity there aro not moro experiments. I beliere if pcoplo would make experiments they would arrire at the ten scconds and thirty scconds interral. The reason is, that the thirty seconds is divided by the ten, and it fell on our cars so distinctly that we took to it at once. I was, unfortunately, Commander of a ehip at the time. I say unfortunately, because I had a little difficulty in getting the boats to make the experiments. It was a little out of my resular duty, and I was very glad, when we arrired at the intervals that wo agreed to as best, to say, "I will do no more." But I think other people should make experiments. I am convinced that if they did they would fix upon the ten and thirty scconds interral. I hare not a doubt about it. I hare nothing more to sar, except that I return my best thanks for your attention. 